\title{
Innate Immunity and the Role of Defensins in Otitis Media
}

\author{
Mark Underwood and \\ Department of Pediatrics, University of California, Davis School of Medicine, Ticon 2 Room 234, \\ 2615 Stockton Boulevard, Sacramento, CA 95817, USA, mark.underwood@ucdmc.ucdavis.edu
}

\section{Lauren Bakaletz}

The Research Institute at Nationwide Children's Hospital, Ohio State University College of Medicine, Columbus, OH, USA

\begin{abstract}
Otitis media is the most common pediatric disease in developed countries and a significant cause of morbidity and hearing loss in developing countries. The innate immune system is essential to protecting the middle ear from infection. Defensins, broad-spectrum cationic antimicrobial peptides, have been implicated in prevention of and the early response to acute otitis media; however, the mechanisms by which defensins and other antimicrobial molecules mediate this protection have not been completely elucidated. In both animal otitis media models and human middle ear epithelial cell culture models, $\beta$-defensins are highly induced and effectively kill the common pathogens associated with otitis media. We review the importance of innate immunity in protecting the middle ear and recent advances in understanding the roles of defensins and other antimicrobial molecules in the prevention and treatment of otitis media. The extremely high prevalence of otitis media, in spite of sophisticated innate and adaptive immune systems, is a vexing problem for clinicians and scientists. We therefore also review mechanisms by which bacteria evade innate immune defenses.
\end{abstract}

\section{Keywords}

Otitis; Otitis media; Pathogenesis; Innate immunity; Defensin; Antimicrobial peptide

\section{Introduction}

Otitis media (OM) is one of the most common diseases of childhood. In developing countries, it is a significant cause of deafness and chronic suppurative otitis. In developed countries, OM also accounts for more office visits, surgeries, and antibiotic purchases than any other disease, with estimated annual costs of 400 million dollars in Australia, 600 million dollars in Canada, and up to 4 billion dollars in the United States [1-3]. As many as $20 \%$ of young children with viral upper respiratory infections develop OM [4]. Acute OM often resolves spontaneously, but chronic OM, recurrent acute OM, and OM with effusion are longer lasting and thereby constitute significant causes of hearing loss. Pathogenesis is multifactorial and includes eustachian tube dysfunction (resulting from small size, functional immaturity, viral respiratory infections, allergy, environmental smoke exposure, and genetic syndromes), invasion of the middle ear space by bacteria and/or viruses, inflammation, and in some cases the formation of biofilms $[5,6 \bullet]$.

Dr. Underwood reported no potential conflicts of interest relevant to this article. 
In healthy children, the middle ear is generally believed to be sterile. OM is a polymicrobial infection caused by synergism between upper respiratory viruses (most commonly influenza A, respiratory syncytial virus [RSV], adenovirus, and rhinovirus) and several predominant commensal bacteria that commonly colonize the nasopharynx. Streptococcus pneumoniae (SP), nontypeable Haemophilus influenzae (NTHI), and Moraxella catarrhalis (MC) are the most common bacteria isolated by standard culture techniques in acute OM [7•]. The introduction of vaccination against common pediatric strains of SP has resulted in a higher prevalence of NTHI and strains of SP not included in the vaccine [8]. Nonculture polymerase chain reaction techniques confirm the prevalence of these bacteria in acute OM, with the possible addition of a fourth species: Alloiococcus otitidis $[9,10]$. In cases of chronic OM and recurrent acute OM, biofilms containing SP, NTHI, coagulase-negative staphylococci, or Staphylococcus aureus appear to be common [11]. Biofilm formation may protect the bacteria from the adaptive and innate immune systems of the host and increase resistance to some antibiotics up to 1,000-fold [12]. Pseudomonas aeruginosa is not a common pathogen in acute OM but is the most common organism isolated in chronic suppurative otitis and in cholesteatomatous otitis [13, 14•, 15].

In 2004, the American Academy of Pediatrics and the American Academy of Family Physicians recommended the option of "watchful waiting," or observation without antibiotic treatment, for select populations of children with acute OM [16]. A second clinical practice guideline recommended avoidance of antibiotics for OM with effusion [17]. In spite of these recommendations, rates of prescription of antibiotics for acute OM have not decreased [18•]. Unnecessary prescribing of antibiotics for $\mathrm{OM}$ is a major contributor to increasing and multiple antibiotic resistance among all three genera of bacteria typically responsible for OM [19]. The need for development of non-antibiotic approaches to prevent and treat OM underscores the importance of understanding the mechanisms by which the healthy middle ear and eustachian tube are protected from bacterial invasion.

The present review begins with a brief overview of the innate immune system in OM, then focuses on defensins and other promising antimicrobial peptides and their roles in protecting the middle ear (Fig. 1).

\section{Innate Immunity of the Middle Ear}

\section{Signaling}

In the healthy naïve host, the sensors and effectors of the innate immune system are responsible for quickly identifying and clearing pathogens from the middle ear. Epithelial cells, dendritic cells, and mast cells in the uppermost airway, including the eustachian tube and middle ear, express a variety of pattern-recognition receptors that recognize bacterial cell surface molecules and activate a wide range of effector molecules. The importance of several Toll-like receptors (TLRs) and the closely associated MyD88/nuclear factor- $\mathrm{KB}$ pathway in OM was reviewed recently [20]. In mice, deficiency or absence of genes that encode for receptors (TLR2, TLR4, TLR9), signaling molecules (MyD88, TRIF), or downstream targets (tumor necrosis factor) leads to the inability to clear OM. Mechanisms for this deficit include persistent thickening of the middle ear mucosa, delayed recruitment of neutrophils and macrophages (though once finally recruited, these cells tend to persist longer), and deficient phagocytosis and intracellular killing of pathogens. The result is persistence of viable bacteria in the middle ear $[21,22 \bullet \bullet, 23 \bullet \bullet$.

\section{Cellular Response}

The cells of the innate immune system can be grouped according to their major functions: phagocytosis (neutrophils, macrophages), barriers (keratinocytes, epithelial cells), signaling (dendritic cells, epithelial cells, fibroblasts, macrophages), and secretion (epithelial cells, 
eosinophils, basophils, mast cells, and natural killer cells). The influx of neutrophils early in acute OM follows opsonization by complement and leads to rapid phagocytosis of bacteria. Within the neutrophil, the phagosome fuses with the lysosome, which has an acidic environment and contains free radicals, acid hydrolases, lactoferrin, lysozyme, and several defensins. The neutrophil is short-lived and is subsequently phagocytosed by macrophages.

Several of the pathogens of OM have developed protective mechanisms against destruction by neutrophils. SP produce at least three exoglycosidases, which deglycosylate human complement, thus preventing opsonization [24]. NTHI are able to avoid phagocytosis by potently stimulating the host to form neutrophil extracellular traps, a niche in which this pathogen is relatively protected [25].

\section{Interactions Between Innate and Adaptive Immunity}

The innate immune system is primarily responsible for immediate and nonspecific responses to infection, whereas adaptive immunity provides long-term protection based on memory of a specific invader. Interactions and overlap between the two components of mammalian immunity are complex. The protective benefit of pneumococcal vaccination against $\mathrm{OM}$ caused by the strains contained in the vaccine is strong evidence of the importance of adaptive immunity in this disease. The essential nature of interactions between innate and adaptive immunity is demonstrated by the attenuated responses in mucosal $\operatorname{IgA}$, systemic $\mathrm{IgG}$, and T-helper type 1 (Th1) immune responses in the TLR4 mutant mouse compared with the wild type following vaccination with an outer membrane protein of NTHI [26••]. The increased prevalence of OM in patients with allergy or asthma is further evidence of the important interactions between innate and adaptive immunity in the middle ear.

Cytokines and chemokines interconnect components of the innate and adaptive immune systems. A classic example is viral activation of epithelial cells, smooth muscle cells, and fibroblasts (through recognition of viral double-stranded RNA [dsRNA] by TLR3 and other mechanisms) to produce cytokines and chemokines. For instance, dsRNA stimulates human nasal fibroblasts to produce CCL5 and CXCL8 [27], and rhinovirus infection causes smooth muscle cells to produce interleukin (IL)-6 and CXCL8 [28]. In the presence of Th2 cytokines, IL-4 and IL-13, dsRNA stimulates fibroblasts to produce CCL17, further increasing the $\mathrm{Th} 2$ response [29].

\section{Defensins}

Defensins are broad-spectrum antimicrobial peptides expressed by all studied species of mammals, birds, invertebrates, and plants. They are an important weapon in the arsenal of the innate immune system, providing rapid response protection from pathogens and shaping the microbiota of several important anatomic niches [30,31]. They share the following common structural characteristics: small peptides (30-45 amino acids), rich in cationic amino acids so that they have a net positive charge, and stabilized by 3 disulfide bonds that protect them from degradation by proteases [32-34]. In humans, $\alpha$-defensins are produced in large quantities in the granules of neutrophils and in the Paneth cells of the small intestine, whereas $\beta$-defensins are produced by epithelial cells in the upper and lower airway (including the middle ear), as well as by colonic enterocytes, keratinocytes, corneal and conjunctival cells, and the genitourinary tract.

Most defensins are directly antimicrobial at micromolar concentrations and have activity against a variety of bacteria, viruses, fungi, and protozoa. Killing mechanisms may be multifaceted; the predominant mechanism is likely formation of a pore within the microbial membrane. In addition, some defensins can inhibit bacterial toxins, including the cytolysin PLY produced by SP [35]. Some of the defensins have proinflammatory activities, 
stimulating cytokine and chemokine expression or acting as chemoattractants for neutrophils, mast cells, memory T cells, and dendritic cells [36]. The recent description of self-assembling nanonets of one of the human Paneth cell $\alpha$-defensins to immobilize Salmonella spp in the lumen of the small intestine is a compelling example of the diversity of biological mechanisms of these peptides (Chu, unpublished data). The defensins and other antimicrobial peptides described in this review are summarized in Table 1.

\section{Defensins and Animal Models of Otitis Media}

The chinchilla is an exotic but compelling model of OM due to its anatomic similarities to the human and the possibility of creating polymicrobial infections [37•]. The chinchilla expresses a defensin in the middle ear (chinchilla $\beta$-defensin 1 [CBD1]), which is orthologous to human $\beta$-defensin (HBD) 3 and has potent antimicrobial activity against NTHI, SP, and MC [38]. Some middle ear pathogens are able to influence expression of CBD1. When the chinchilla is infected with RSV, expression of CBD1 is suppressed at the mRNA and the protein levels, resulting in increased colonization with NTHI in the upper respiratory tract. Chinchilla middle ear epithelial cells infected with RSV, MC, or SP express lower levels of CBD1, but this effect is not seen with influenza A, adenovirus, or NTHI [39]. Furthermore, intranasal treatment of chinchillas with recombinant CBD1 significantly decreased NTHI colonization in nasopharyngeal lavage fluid [40••].

The mouse expresses multiple $\alpha$-defensins in the small intestine and at least four $\beta$-defensins in epithelial cells, but its neutrophils do not express defensins. In a murine model involving induction of OM by inoculation of the middle ear with Escherichia coli endotoxin, none of the $\alpha$-defensins are detected in the healthy middle ear or in OM. Mouse $\beta$-defensin 1 is expressed constitutively in healthy middle ear mucosa and in eustachian tube mucosa and does not change in this model of acute OM. Mouse $\beta$-defensins 2, 3, and 4 are not expressed in the healthy middle ear or eustachian tube mucosae but are highly induced in these tissues in endotoxin-mediated OM [41]. Recombinant mouse $\beta$-defensin 3 (the ortholog of HBD2) is highly effective at killing filamentous fungi and yeasts and moderately effective at killing gram-positive bacteria, with marginal activity against gram-negative bacteria [42]. Recombinant mouse $\beta$-defensin 2 has potent antiviral activity against influenza A [43•].

\section{Human Defensins and Otitis Media}

HBD2 is a potent antimicrobial peptide. Killing of NTHI, MC, and two strains of SP by HBD2 at low concentrations has been demonstrated by radial diffusion assay, liquid broth assay, and with electron microscopy [44]. HBD2 expression is induced in human middle ear epithelial cells by at least two distinct mechanistic pathways. IL-1 $\alpha$ induces HBD2 expression through the Raf-MEK1/2 extracellular signal-related kinase mitogen-activated protein (MAP) kinase pathway [45]. In addition, NTHI is recognized by TLR2 and induces HBD2 expression through the MyD88-IRAKI-TRAF6-MKK3/6-p38 MAP kinase signal transduction pathway [46]. Direct measurement of HBDs in the middle ear fluid from patients with acute OM has not yet been reported.

Human $\alpha$-defensins 1 to 4 are expressed in neutrophil granules and are important in destroying phagocytosed bacteria. Of the four, human neutrophil peptide-1 is the most potent antimicrobial, with activity comparable to that of $\mathrm{HBD} 2$, against several strains of NTHI [47]. In a rat model of OM caused by direct inoculation with NTHI, recruitment of neutrophils to the middle ear peaked on day 4 , with macrophage recruitment peaking on day 7, and maximal lymphocyte recruitment on day 14 [48]. Infants with severe congenital neutropenia have a high incidence of OM. The precise role of the neutrophil defensins in OM has not been explored. 


\section{Other Antimicrobial Molecules}

Cathelicidins are cationic peptides with widely diverse activities. In addition to being potent antimicrobials, they are chemotactic for neutrophils, monocytes, and dendritic cells, and are able to inactivate endotoxin and stimulate release of histamine from mast cells. In the chinchilla, a cathelicidin orthologous to the mouse CRAMP has been identified that is expressed throughout the upper respiratory tract, including the middle ear and eustachian tube, and is highly effective at killing NTHI and MC but less potent against SP [39]. Some middle ear pathogens are able to alter expression of cathelicidins, as has been described with $\beta$-defensins. In chinchilla middle ear epithelial cells, infection with influenza A suppressed CRAMP expression, as did infection with MC, while infection with RSV and adenovirus had no effect, and infection with NTHI and SP caused an increase [39]. A synthetic peptide, P60.4-Ac, based on the structure of the human cathelicidin LL-37, neutralized the effects of endotoxin and lipoteichoic acid on sinus epithelial cells in culture [49]. Whether direct instillation of such a peptide into the nasopharynx would be effective in treatment of antibiotic-resistant $\mathrm{OM}$ is unclear.

\section{Lysozyme}

Lysozyme is an antimicrobial enzyme that degrades the peptidoglycan of the bacterial cell wall. It is expressed by many mucosal surfaces, including the gut, eye, and upper respiratory tract. Lysozyme has synergistic killing effects against SP when combined with HBD2 [44]. In a mouse depleted of lysozyme, susceptibility to OM caused by injection of SP into the middle ear increased, suggesting that middle ear lysozyme plays a role in protection against OM [50].

\section{Bacteriocins}

Bacteriocins are peptides synthesized by bacteria with antimicrobial activity predominantly against closely related species. Several strains of $\alpha$-hemolytic streptococci produce bacteriocins. Among them, Streptococcus salivarius has been proposed as an ideal probiotic agent to alter the oral flora [51•]. A decade ago, a clinical trial involved spraying $\alpha$ hemolytic streptococci directly into the noses of 130 children with recurrent acute OM. The treated children had fewer episodes of acute OM [52]. Subsequent studies have demonstrated fewer bacteriocin-producing bacteria ( $\alpha$-hemolytic streptococci, nonhemolytic streptococci, peptostreptococci, and Prevotella spp) in the adenoidal tissue of otitis-prone children [53]. Peptide ST4SA is an amphiphilic cationic peptide produced by Enterococcus mundtii; it is unusual in that it interacts with the negatively charged cell membranes of both gram-positive and gram-negative organisms, creating pores and causing leakage of small intracellular molecules such as DNA and enzymes [54]. This peptide is stable over a wide $\mathrm{pH}$ and temperature range, is bacteriostatic against many strains of SP and Pseudomonas spp, and suppressed growth of bacteria recovered from middle ear aspirates [54].

\section{Surfactant Proteins}

Surfactant proteins opsonize, aggregate, and promote phagocytosis of bacteria. Some also have direct broad-spectrum antimicrobial activity. In a guinea pig model of OM with effusion, nebulized bovine surfactant administered intranasally decreased edema and reduced the passive opening pressure of the eustachian tube [55•]. The demonstrated effect is likely predominantly mechanical rather than antimicrobial. SPLUNC1 is a newly described antimicrobial protein secreted by the mucus cells and submucosal glands of the upper airway. This protein has broad-spectrum antimicrobial activity, reduces biofilms produced by $P$. aeruginosa, and functions as a surfactant that reduced surface tension at the air-liquid interface in the upper airway, including the eustachian tube. In the chinchilla model, inhibition of SPLUNC1 with selective small inhibitory RNA did not increase the 
bacterial load of NTHI within the middle ear but led to eustachian tube dysfunction, likely due to decreased mucociliary clearance [56•].

\section{Cationic Peptides}

Cationic peptides that bind to bacterial cell surfaces can be identified by studying the affinity of large peptide phage display libraries for a specific organism. This approach identified five small peptides that bind to the cell surface of NTHI and are bactericidal in the low micromolar range against all strains of $H$. influenzae tested [47]. All five peptides were highly active when expressed as part of the phage coat; however, the linearized forms lacked activity, dampening enthusiasm for their development as synthetic antimicrobials. A similar approach may be useful in identifying antimicrobial peptides capable of binding to multidrug-resistant organisms.

\section{Halocidin}

Halocidin is a small $(3.4 \mathrm{kDa})$ peptide identified in the hemocytes of the tunicate Halocynthia aurantium. It consists of two subunits covalently bound by a single cysteine disulfide bond. Synthetic peptides of the monomeric and dimeric forms of one of the subunits are highly effective at killing both methicillin-resistant $S$. aureus and multidrugresistant $P$. aeruginosa [57]. Compared with topical ofloxacin, the dimeric form (Di-K19Hc) was significantly more potent against these drug-resistant organisms and better at clearing infected middle ear fluid. Importantly, unlike gentamicin, there was no evidence of damage to the hair cells of the organ of Corti with Di-K19Hc [58•].

\section{Xylitol}

Xylitol is a five-carbon sugar alcohol that inhibits attachment of $H$. influenzae and SP to nasopharyngeal cells and inhibits growth of $\alpha$-hemolytic streptococci, including SP. One mechanism of action appears to be inhibition of capsule formation and biofilm formation by SP [59•]. Clinical trials of xylitol-containing chewing gum have demonstrated decreases in OM of 30\% to $40 \%$ in otitis-prone children [60], although from a practical standpoint, the patients at highest risk of OM are too young to chew gum. Delivering xylitol with a "slowrelease pacifier" to prevent caries in infants has been explored [61], but such an approach for infants with recurrent OM has not yet been studied.

\section{Resistance to Antimicrobial Peptides}

Many pathogenic bacteria have developed methods of resistance to killing by antimicrobial peptides. One example is particularly pertinent to OM: NTHI that contain the sap (sensitivity to anti-microbial peptides) operon are able to resist killing by chinchilla $\beta$ defensin, whereas a mutation in one of the sap genes confers susceptibility to defensinmediated killing [62]. The sap gene products are a family of at least six proteins that detect the presence of $\beta$-defensin, upregulate production of the sap genes, and mediate potassium uptake, thereby protecting the pathogen [63].

A second example is the ability of $S$. aureus and $P$. aeruginosa to alter their peptidoglycan via the addition of lysine or alanine, respectively, altering the net surface charge and decreasing affinity for binding of cationic antimicrobial peptides [64]. Whether the more common organisms of acute $\mathrm{OM}$ are able to avoid killing by antimicrobial peptides in this way is not known. 


\section{Conclusions}

Otitis media is a common, expensive, and vexing infection. As antibiotic resistance has increased, guidelines for minimizing use of antibiotics for OM have been published. However, adherence to these guidelines has been poor [65•]. Vaccine development is promising [66], but experience suggests that new strains may replace the strains included in new vaccines; this is particularly relevant for SP. Antimicrobial peptides and proteins are evolutionarily ancient, with minimal resistance developing in spite of long use by virtually all plants, vertebrates, and invertebrates. Defensins and other antimicrobial molecules play an important role in protecting the middle ear and responding to infection of this unique niche. The extremely high prevalence of OM in young children suggests that the innate immune system is easily circumvented in this vulnerable population. The development of formulations of antimicrobial molecules that could be directly instilled into the nasopharynx and their potential use in the treatment of resistant and chronic OM may represent a novel therapeutic approach, thereby adding a hopeful chapter to what heretofore has been the troublesome saga of OM.

\section{Acknowledgments}

Dr. Underwood has received research support from National Institutes of Health grant no. HD059127. This publication was also made possible by grant no. UL1 RR024146 from the National Center for Research Resources, a component of the National Institutes of Health.

Disclosure Dr. Bakaletz has received grant support from GlaxoSmithKline Biologicals, received seminar speaker honoraria from various universities in the United States, and had travel/accommodations expenses covered for participation on a scientific advisory board by GlaxoSmithKline Biologicals. Her institution holds a licensed patent portfolio in conjunction with GlaxoSmithKline Biologicals, and a portion of royalties from a licensing agreement are distributed to named inventors by GlaxoSmithKline Biologicals.

\section{References}

1. Taylor PS, Faeth I, Marks MK, Del Mar CB, Skull SA, Pezzullo ML, Havyatt SM, Coates HL. Cost of treating otitis media in Australia. Expert Rev Pharmacoecon Outcomes Res. 2009; 9:133-141. [PubMed: 19402800]

2. Coyte PC, Asche CV, Elden LM. The economic cost of otitis media in Canada. Int J Pediatr Otorhinolaryngol. 1999; 49:27-36. [PubMed: 10428403]

3. O’Brien MA, Prosser LA, Paradise JL, Ray GT, Kulldorff M, Kurs-Lasky M, Hinrichsen VL, Mehta J, Colborn DK, Lieu TA. New vaccines against otitis media: projected benefits and costeffectiveness. Pediatrics. 2009; 123:1452-1463. [PubMed: 19482754]

4. Kalu SU, Ataya RS, McCormick DP, Patel JA, Revai K, Chonmaitree T. Clinical spectrum of acute otitis media complicating upper respiratory tract viral infection. Pediatr Infect Dis J. 2011; 30:9599. [PubMed: 20711085]

5. Post JC, Hiller NL, Nistico L, Stoodley P, Ehrlich GD. The role of biofilms in otolaryngologic infections: update 2007. Curr Opin Otolaryngol Head Neck Surg. 2007; 15:347-351. [PubMed: 17823552]

6. Hoa M, Syamal M, Schaeffer MA, Sachdeva L, Berk R, Coticchia J. Biofilms and chronic otitis media: an initial exploration into the role of biofilms in the pathogenesis of chronic otitis media. Am J Otolaryngol. 2010; 31:241-245. [PubMed: 20015753] Analysis of biofilms on adenoidal tissue removed from children with recurrent OM, OM with effusion, and sleep apnea showed marked differences. Biofilm formation was extensive in recurrent OM, moderate in OM with effusion, and minimal in sleep apnea. This suggests a significant role of biofilms in recurrent OM.

7. Murphy TF, Bakaletz LO, Smeesters PR. Microbial interactions in the respiratory tract. Pediatr Infect Dis J. 2009; 28:S121-S126. [PubMed: 19918134] This article summarizes the interactions and competition between the major pathogens of OM and the importance of biofilm formation in chronic OM. 
8. Revai K, McCormick DP, Patel J, Grady JJ, Saeed K, Chonmaitree T. Effect of pneumococcal conjugate vaccine on nasopharyngeal bacterial colonization during acute otitis media. Pediatrics. 2006; 117:1823-1829. [PubMed: 16651345]

9. Kaur R, Adlowitz DG, Casey JR, Zeng M, Pichichero ME. Simultaneous assay for four bacterial species including Alloiococcus otitidis using multiplex-PCR in children with culture negative acute otitis media. Pediatr Infect Dis J. 2010; 29:741-745. [PubMed: 20335823]

10. De Baere T, Vaneechoutte M, Deschaght P, Huyghe J, Dhooge I. The prevalence of middle ear pathogens in the outer ear canal and the nasopharyngeal cavity of healthy young adults. Clin Microbiol Infect. 2010; 16:1031-1035. [PubMed: 19895585]

11. Paluch-Oles J, Magrys A, Koziol-Montewka M, Niedzielski A, Niedzwiadek J, Niedzielska G, Kotowski M. The phenotypic and genetic biofilm formation characteristics of coagulase-negative staphylococci isolates in children with otitis media. Int J Pediatr Otorhinolaryngol. 2010; 75:126130. [PubMed: 21093067]

12. Kaji C, Watanabe K, Apicella MA, Watanabe H. Antimicrobial effect of fluoroquinolones for the eradication of nontypeable Haemophilus influenzae isolates within biofilms. Tohoku J Exp Med. 2008; 214:121-128. [PubMed: 18285669]

13. Lee SK, Lee MS, Jung SY, Byun JY, Park MS, Yeo SG. Antimicrobial resistance of Pseudomonas aeruginosa from otorrhea of chronic suppurative otitis media patients. Otolaryngol Head Neck Surg. 2010; 143:500-505. [PubMed: 20869558]

14. Shim HJ, Park CH, Kim MG, Lee SK, Yeo SG. A pre- and postoperative bacteriological study of chronic suppurative otitis media. Infection. 2010; 38:447-452. [PubMed: 20700754] This was a survey of the microbiota in chronic suppurative otitis before and after surgery. The major organisms were S. aureus, coagulase-negative staphylococci, and P. aeruginosa, with the latter most likely to persist after surgery.

15. Ricciardiello F, Cavaliere M, Mesolella M, Iengo M. Notes on the microbiology of cholesteatoma: clinical findings and treatment. Acta Otorhinolaryngol Ital. 2009; 29:197-202. [PubMed: 20161877]

16. American Academy of Pediatrics SoMoAOM. Diagnosis and management of acute otitis media. Pediatrics. 2004; 113:1451-1465. [PubMed: 15121972]

17. American Academy of Pediatrics SoOMwE. Otitis media with effusion. Pediatrics. 2004; 113:1412-1429. [PubMed: 15121966]

18. Coco A, Vernacchio L, Horst M, Anderson A. Management of acute otitis media after publication of the 2004 AAP and AAFP clinical practice guideline. Pediatrics. 2010; 125:214-220. [PubMed: 20100746] This was a comparison of treatment of otitis in the United States for the 30 months before and the 30 months after publication of the 2004 guidelines. There was no significant change in the number of patients with otitis who were not treated with antibiotics, but there was an increase in use of amoxicillin and a decrease in use of amoxicillin-clavulanate.

19. Vergison A, Dagan R, Arguedas A, Bonhoeffer J, Cohen R, Dhooge I, Hoberman A, Liese J, Marchisio P, Palmu AA, Ray GT, Sanders EA, Simoes EA, Uhari M, van Eldere J, Pelton SI. Otitis media and its consequences: beyond the earache. Lancet Infect Dis. 2010; 10:195-203. [PubMed: 20185098]

20. Leichtle A, Lai Y, Wollenberg B, Wasserman SI, Ryan AF. Innate signaling in otitis media: pathogenesis and recovery. Curr Allergy Asthma Rep. 2011; 11:78-84. [PubMed: 21049294]

21. Hernandez M, Leichtle A, Pak K, Ebmeyer J, Euteneuer S, Obonyo M, Guiney DG, Webster NJ, Broide DH, Ryan AF, Wasserman SI. Myeloid differentiation primary response gene 88 is required for the resolution of otitis media. J Infect Dis. 2008; 198:1862-1869. [PubMed: 18986247]

22. Leichtle A, Hernandez M, Pak K, Yamasaki K, Cheng CF, Webster NJ, Ryan AF, Wasserman SI. TLR4-mediated induction of TLR2 signaling is critical in the pathogenesis and resolution of otitis media. Innate Immun. 2009; 15:205-215. [PubMed: 19586996] This article describes inflammatory responses to NTHI in wild-type, TLR2 knockout, and TLR4 knockout mice. Both knockout groups demonstrated decreased tumor necrosis factor induction, delayed bacterial clearance, and persistent inflammation compared with wild-type mice. TLR2 induction was decreased in the TLR4 knockouts, suggesting that TLR4 induces TLR2 expression; both receptors are important in the immune response to NTHI. 
23. Leichtle A, Hernandez M, Lee J, Pak K, Webster NJ, Wollenberg B, Wasserman SI, Ryan AF. The role of DNA sensing and innate immune receptor TLR9 in otitis media. Innate Immun. 2011 TLR9 senses bacterial DNA. TLR9 knockout mice demonstrate delayed bacterial clearance and persistent inflammation after middle ear infection with NTHI compared with wild-type mice. TLR9 is also important in the immune response to NTHI.

24. Dalia AB, Standish AJ, Weiser JN. Three surface exoglycosidases from Streptococcus pneumoniae, NanA, BgaA, and StrH, promote resistance to opsonophagocytic killing by human neutrophils. Infect Immun. 2010; 78:2108-2116. [PubMed: 20160017]

25. Juneau RA, Pang B, Weimer KE, Armbruster CE, Swords WE. Nontypeable Haemophilus influenzae initiates formation of neutrophil extracellular traps. Infect Immun. 2011; 79:431-438. [PubMed: 20956567]

26. Hirano T, Kodama S, Moriyama M, Kawano T, Suzuki M. The role of Toll-like receptor 4 in eliciting acquired immune responses against nontypeable Haemophilus influenzae following intranasal immunization with outer membrane protein. Int J Pediatr Otorhinolaryngol. 2009; 73:1657-1665. [PubMed: 19765832] Outer membrane proteins of NTHI are promising vaccine candidates. Comparison of mucosal and systemic immune responses to intranasal instillation of NTHI outer membrane proteins in wild-type and TLR4 knockout mice demonstrated the importance of the TLR4 receptor in response to this potential vaccine.

27. Takahashi N, Yamada T, Narita N, Fujieda S. Double-stranded RNA induces production of RANTES and IL-8 by human nasal fibroblasts. Clin Immunol. 2006; 118:51-58. [PubMed: 16253565]

28. Oliver BG, Johnston SL, Baraket M, Burgess JK, King NJ, Roth M, Lim S, Black JL. Increased proinflammatory responses from asthmatic human airway smooth muscle cells in response to rhinovirus infection. Respir Res. 2006; 7:71. [PubMed: 16670028]

29. Nonaka M, Ogihara N, Fukumoto A, Sakanushi A, Pawankar R, Yagi T. Poly(I:C) synergizes with Th2 cytokines to induce TARC/CCL17 in middle ear fibroblasts established from mucosa of otitis media with effusion. Acta Otolaryngol. 2009 Suppl:57-62. [PubMed: 18607981]

30. Salzman NH, Hung K, Haribhai D, Chu H, Karlsson-Sjoberg J, Amir E, Teggatz P, Barman M, Hayward M, Eastwood D, Stoel M, Zhou Y, Sodergren E, Weinstock GM, Bevins CL, Williams CB, Bos NA. Enteric defensins are essential regulators of intestinal microbial ecology. Nat Immunol. 2010; 11:76-83. [PubMed: 19855381]

31. Salzman NH, Underwood MA, Bevins CL. Paneth cells, defensins, and the commensal microbiota: a hypothesis on intimate interplay at the intestinal mucosa. Semin Immunol. 2007; 19:70-83. [PubMed: 17485224]

32. Ganz T. Defensins: antimicrobial peptides of innate immunity. Nat Rev Immunol. 2003; 3:710720. [PubMed: 12949495]

33. Lehrer RI. Primate defensins. Nat Rev Microbiol. 2004; 2:727-738. [PubMed: 15372083]

34. Zasloff M. Antimicrobial peptides of multicellular organisms. Nature. 2002; 415:389-395. [PubMed: 11807545]

35. Lehrer RI, Jung G, Ruchala P, Wang W, Micewicz ED, Waring AJ, Gillespie EJ, Bradley KA, Ratner AJ, Rest RF, Lu W. Human alpha-defensins inhibit hemolysis mediated by cholesteroldependent cytolysins. Infect Immun. 2009; 77:4028-4040. [PubMed: 19581399]

36. Yang D, Liu ZH, Tewary P, Chen Q, de la Rosa G, Oppenheim JJ. Defensin participation in innate and adaptive immunity. Curr Pharm Des. 2007; 13:3131-3139. [PubMed: 17979754]

37. Bakaletz LO. Chinchilla as a robust, reproducible and polymicrobial model of otitis media and its prevention. Expert Rev Vaccines. 2009; 8:1063-1082. [PubMed: 19627188] This article presents a description of the chinchilla as the gold standard for polymicrobial OM.

38. Harris RH, Wilk D, Bevins CL, Munson RS Jr, Bakaletz LO. Identification and characterization of a mucosal antimicrobial peptide expressed by the chinchilla (Chinchilla lanigera) airway. J Biol Chem. 2004; 279:20250-20256. [PubMed: 14996845]

39. McGillivary G, Ray WC, Bevins CL, Munson RS Jr, Bakaletz LO. A member of the cathelicidin family of antimicrobial peptides is produced in the upper airway of the chinchilla and its mRNA expression is altered by common viral and bacterial co-pathogens of otitis media. Mol Immunol. 2007; 44:2446-2458. [PubMed: 17113647] 
40. McGillivary G, Mason KM, Jurcisek JA, Peeples ME, Bakaletz LO. Respiratory syncytial virusinduced dysregulation of expression of a mucosal beta-defensin augments colonization of the upper airway by non-typeable Haemophilus influenzae. Cell Microbiol. 2009; 11:1399-1408. [PubMed: 19500108] This study demonstrated an important mechanism underlying polymicrobial OM. Infection with RSV inhibits chinchilla $\beta$-defensin expression, thereby allowing NTHI to flourish.

41. Jin Shin D, Gan-Undram S, Jin Kim S, Joon Jun Y, Jung Im G, Hyun Jung H. Expression of betadefensins in the tubotympanum of experimental otitis media. Acta Otolaryngol. 2006; 26:10401045. [PubMed: 16923707]

42. Jiang Y, Wang Y, Wang B, Yang D, Yu K, Yang X, Liu F, Jiang Z, Li M. Antifungal activity of recombinant mouse beta-defensin 3. Lett Appl Microbiol. 2010; 50:468-473. [PubMed: 20337925]

43. Gong T, Jiang Y, Wang Y, Yang D, Li W, Zhang Q, Feng W, Wang B, Jiang Z, Li M. Recombinant mouse beta-defensin 2 inhibits infection by influenza A virus by blocking its entry. Arch Virol. 2010; 155:491-498. [PubMed: 20195655] Mouse $\beta$-defensin 2 has strong antiviral activity against influenza $A$ and is protective in mice when administered before or immediately after a lethal dose of influenza A.

44. Lee HY, Andalibi A, Webster P, Moon SK, Teufert K, Kang SH, Li JD, Nagura M, Ganz T, Lim DJ. Antimicrobial activity of innate immune molecules against Streptococcus pneumoniae, Moraxella catarrhalis and nontypeable Haemophilus influenzae. BMC Infect Dis. 2004; 4:12. [PubMed: 15125783]

45. Moon SK, Lee HY, Pan H, Takeshita T, Park R, Cha K, Andalibi A, Lim DJ. Synergistic effect of interleukin 1 alpha on nontypeable Haemophilus influenzae-induced up-regulation of human betadefensin 2 in middle ear epithelial cells. BMC Infect Dis. 2006; 6:12. [PubMed: 16433908]

46. Lee HY, Takeshita T, Shimada J, Akopyan A, Woo JI, Pan H, Moon SK, Andalibi A, Park RK, Kang SH, Kang SS, Gellibolian R, Lim DJ. Induction of beta defensin 2 by NTHi requires TLR2 mediated MyD88 and IRAK-TRAF6-p38MAPK signaling pathway in human middle ear epithelial cells. BMC Infect Dis. 2008; 8:87. [PubMed: 18578886]

47. Bishop-Hurley SL, Schmidt FJ, Erwin AL, Smith AL. Peptides selected for binding to a virulent strain of Haemophilus influenzae by phage display are bactericidal. Antimicrob Agents Chemother. 2005; 49:2972-2978. [PubMed: 15980377]

48. Alzbutiene G, Hermansson A, Caye-Thomasen P, Kinduris V. Tympanic membrane changes in experimental acute otitis media and myringotomy. Medicina (Kaunas). 2008; 44:313-321. [PubMed: 18469509]

49. Vonk MJ, Hiemstra PS, Grote JJ. An antimicrobial peptide modulates epithelial responses to bacterial products. Laryngoscope. 2008; 118:816-820. [PubMed: 18300705]

50. Shimada J, Moon SK, Lee HY, Takeshita T, Pan H, Woo JI, Gellibolian R, Yamanaka N, Lim DJ. Lysozyme M deficiency leads to an increased susceptibility to Streptococcus pneumoniae-induced otitis media. BMC Infect Dis. 2008; 8:134. [PubMed: 18842154]

51. Wescombe PA, Heng NC, Burton JP, Chilcott CN, Tagg JR. Streptococcal bacteriocins and the case for Streptococcus salivarius as model oral probiotics. Future Microbiol. 2009; 4:819-835. [PubMed: 19722837] This article describes the diverse bacteriocins produced by streptococci. Special emphasis is placed on a promising commensal strain that produces broad-spectrum bacteriocins.

52. Roos K, Hakansson EG, Holm S. Effect of recolonisation with "interfering" alpha streptococci on recurrences of acute and secretory otitis media in children: randomised placebo controlled trial. BMJ. 2001; 322:210-212. [PubMed: 11159619]

53. Brook I. The role of bacterial interference in otitis, sinusitis and tonsillitis. Otolaryngol Head Neck Surg. 2005; 133:139-146. [PubMed: 16025067]

54. Knoetze H, Todorov SD, Dicks LM. A class IIa peptide from Enterococcus mundtii inhibits bacteria associated with otitis media. Int J Antimicrob Agents. 2008; 31:228-234. [PubMed: 18155886]

55. Jang CH, Cho YB, Oh SE, Choi JU, Park H, Choi CH. Effect of nebulized bovine surfactant for experimental otitis media with effusion. Clin Exp Otorhinolaryngol. 2010; 3:13-17. [PubMed: 
20379396] This article explores the novel approach of using nebulized bovine surfactant to reduce eustachian tube opening pressure in a guinea pig model of OM with effusion.

56. McGillivary G, Bakaletz LO. The multifunctional host defense peptide SPLUNC1 is critical for homeostasis of the mammalian upper airway. PLoS One. 2010; 5 e13224. This study demonstrated the role of the antimicrobial peptide SLPUNC1 in maintaining efficient mucociliary middle ear clearance in the chinchilla model of OM.

57. Jang WS, Kim KN, Lee YS, Nam MH, Lee IH. Halocidin: a new antimicrobial peptide from hemocytes of the solitary tunicate, Halocynthia aurantium. FEBS Lett. 2002; 521:81-86. [PubMed: 12067731]

58. Lee YS, Kim YJ, Choi SH, Shin KH, Jang WS, Lee IH, Chung JW. Di-K19Hc, an antimicrobial peptide as new ototopical agent for treatment of otitis media. Acta Otolaryngol. 2010; 130:897903. [PubMed: 20100130] This study demonstrated strong antibacterial activity of a synthetic halocidin against multiple drug-resistant strains of $\mathrm{P}$. aeruginosa and methicillin-resistant $\mathrm{S}$. aureus.

59. Kurola P, Tapiainen T, Sevander J, Kaijalainen T, Leinonen M, Uhari M, Saukkoriipi A. Effect of xylitol and other carbon sources on Streptococcus pneumoniae biofilm formation and gene expression in vitro. Apmis. 2010; 119:135-142. [PubMed: 21208281] Twenty pneumococcal isolates obtained from middle ear aspirates were grown in culture media containing xylitol, glucose, fructose, or combinations of these sugars. Xylitol inhibited bacterial growth and biofilm formation, but glucose and fructose (alone or added to xylose) had the opposite effect.

60. Uhari M, Kontiokari T, Niemela M. A novel use of xylitol sugar in preventing acute otitis media. Pediatrics. 1998; 102:879-884. [PubMed: 9755259]

61. Taipale T, Pienihakkinen K, Alanen P, Jokela J, Soderling E. Dissolution of xylitol from a food supplement administered with a novel slow-release pacifier: preliminary results. Eur Arch Paediatr Dent. 2007; 8:123-125. [PubMed: 17555696]

62. Mason KM, Munson RS Jr, Bakaletz LO. A mutation in the sap operon attenuates survival of nontypeable Haemophilus influenzae in a chinchilla model of otitis media. Infect Immun. 2005; 73:599-608. [PubMed: 15618200]

63. Mason KM, Bruggeman ME, Munson RS, Bakaletz LO. The non-typeable Haemophilus influenzae Sap transporter provides a mechanism of antimicrobial peptide resistance and SapDdependent potassium acquisition. Mol Microbiol. 2006; 62:1357-1372. [PubMed: 17064364]

64. Roy H, Dare K, Ibba M. Adaptation of the bacterial membrane to changing environments using aminoacylated phospholipids. Mol Microbiol. 2009; 71:547-550. [PubMed: 19054327]

65. Haggard M. Poor adherence to antibiotic prescribing guidelines in acute otitis media-obstacles, implications, and possible solutions. Eur J Pediatr. 2011; 170:323-332. [PubMed: 20862492] This article reviews treatment guidelines from several organizations, barriers to compliance with these guidelines, and recommendations for improvement.

66. Murphy TF. Vaccine development for non-typeable Haemophilus influenzae and Moraxella catarrhalis: progress and challenges. Expert Rev Vaccines. 2005; 4:843-853. [PubMed: 16372880]

67. Ericksen B, Wu Z, Lu W, Lehrer RI. Antibacterial activity and specificity of the six human \{alpha\}-defensins. Antimicrob Agents Chemother. 2005; 49:269-275. [PubMed: 15616305]

68. Soehnlein O, Kai-Larsen Y, Frithiof R, Sorensen OE, Kenne E, Scharffetter-Kochanek K, Eriksson EE, Herwald H, Agerberth B, Lindbom L. Neutrophil primary granule proteins HBP and HNP1-3 boost bacterial phagocytosis by human and murine macrophages. J Clin Invest. 2008; 118:34913502. [PubMed: 18787642]

69. Nuding S, Fellermann K, Wehkamp J, Mueller HA, Stange EF. A flow cytometric assay to monitor antimicrobial activity of defensins and cationic tissue extracts. J Microbiol Methods. 2006; 65:335-345. [PubMed: 16182394]

70. Diamond G, Ryan L. Beta-defensins: what are they REALLY doing in the oral cavity? Oral Dis. 2011 Feb 18. (Epub ahead of print).

71. Lai Y, Gallo RL. AMPed up immunity: how antimicrobial peptides have multiple roles in immune defense. Trends Immunol. 2009; 30:131-141. [PubMed: 19217824] 
72. Ibrahim HR, Thomas U, Pellegrini A. A helix-loop-helix peptide at the upper lip of the active site cleft of lysozyme confers potent antimicrobial activity with membrane permeabilization action. J Biol Chem. 2001; 276:43767-43774. [PubMed: 11560930]

73. Jang WS, Kim HK, Lee KY, Kim SA, Han YS, Lee IH. Antifungal activity of synthetic peptide derived from halocidin, antimicrobial peptide from the tunicate, Halocynthia aurantium. FEBS Lett. 2006; 580:1490-1496. [PubMed: 16469314] 


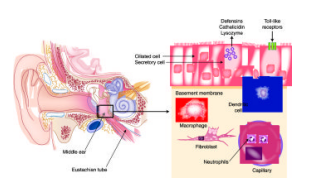

Fig 1.

Innate immunity and the middle ear. Innate immunity includes barrier functions, sensing of pathogenic bacteria (by receptors on and in epithelial cells, dendritic cells, and mast cells), release of antimicrobial peptides and proteins, and recruitment and activity of various effector cells (eg, neutrophils, macrophages, fibroblasts, natural killer cells, and eosinophils) 
Table 1

Antimicrobial molecules in otitis media

\begin{tabular}{|c|c|c|c|c|}
\hline Molecule & Classification & $\begin{array}{l}\text { Human gene } \\
\text { designation }\end{array}$ & $\begin{array}{l}\text { Antimicrobial } \\
\text { activity }\end{array}$ & $\begin{array}{l}\text { Other immune } \\
\text { functions }\end{array}$ \\
\hline \multirow{3}{*}{$\begin{array}{l}\text { Human neutrophil peptides } \\
1-4\end{array}$} & \multirow[t]{3}{*}{$\alpha$-defensins } & DEFAl & \multirow{3}{*}{$\begin{array}{l}\text { Gram-positive and gram- } \\
\text { negative bacteria [67], protozoa, } \\
\text { fungi, and multiple viruses }\end{array}$} & \multirow[t]{3}{*}{ Increase phagocytosis [68] } \\
\hline & & DEFA3 & & \\
\hline & & DEFA4 & & \\
\hline \multirow[t]{4}{*}{ Human $\beta$-defensins $1-4$} & \multirow[t]{4}{*}{$\beta$-defensins } & $D E F B 1$ & \multirow{4}{*}{$\begin{array}{l}\text { Gram-positive and gram- } \\
\text { negative bacteria [69], protozoa, } \\
\text { fungi, and multiple viruses }\end{array}$} & \multirow{4}{*}{$\begin{array}{l}\text { Chemotaxis, induction and } \\
\text { suppression of inflammation [70] }\end{array}$} \\
\hline & & DEFB4 & & \\
\hline & & DEFB103 & & \\
\hline & & DEFB104 & & \\
\hline LL-37 & Cathelicidin & CAMP & $\begin{array}{l}\text { Broad spectrum of bacteria and } \\
\text { viruses }\end{array}$ & $\begin{array}{l}\text { Chemotaxis, modulation of } \\
\text { inflammation [71] }\end{array}$ \\
\hline Lysozyme & Enzyme & $L Y Z$ & $\begin{array}{l}\text { Gram-positive and gram- } \\
\text { negative bacteria, fungi [72] }\end{array}$ & - \\
\hline SPLUNC1 & Protein & PLUNC & Mycoplasma & $\begin{array}{l}\text { Inhibits epithelial sodium channel } \\
\text { activity }\end{array}$ \\
\hline \multicolumn{5}{|c|}{ Synthetic or nonhuman molecules } \\
\hline ST4SA & Bacteriocin & - & $\begin{array}{l}\text { Gram-positive and gram- } \\
\text { negative bacteria }\end{array}$ & - \\
\hline $\mathrm{Hi} 3 / 2$ & \multirow[t]{3}{*}{ Phage peptides } & \multirow[t]{3}{*}{-} & \multirow[t]{3}{*}{ NTHI } & \multirow[t]{3}{*}{-} \\
\hline Hi $3 / 11-13$ & & & & \\
\hline Hi $3 / 17$ & & & & \\
\hline Di-K19H & Synthetic halocidin & - & $\begin{array}{l}\text { Antibiotic-resistant bacteria, } \\
\text { fungi [73] }\end{array}$ & - \\
\hline Xylitol & Sugar alcohol & - & SP, NTHI & - \\
\hline
\end{tabular}

NTHI—nontypeable Haemophilus influenzae; SP—Streptococcus pneumoniae 